DOI: $\underline{10.32702 / 2307-2105-2021.4 .109}$

УДК 338.2

\author{
L. Say
}

PhD in Economics, Associate Professor,

Associate Professor of the Department of Management and International Business,

National University "Lviv Polytechnic", Lviv

ORCID ID: 0000-0002-5081-4235

L. Gnylianska

PhD in Economics, Associate Professor,

Associate Professor of the Department of Management and International Business,

National University "Lviv Polytechnic", Lviv

ORCID ID: 0000-0003-2924-7165

K. Kushner

Master's student of the Department of Management and International Business,

National University "Lviv Polytechnic", Lviv

ORCID ID: 0000-0003-0962-0196

\title{
PECULIARITIES OF FRANCHISING DEVELOPMENT IN A PANDEMIC CONDITION
}

\author{
Л. П. Сай, \\ к. е. н., доцент, доцент кафедри менеджменту і міжнародного підприємництва \\ Національного університету «Львівська політехніка», \\ м. Львів \\ Л. Й. Гнилянська, \\ к. е. н., доцент, доцент кафедри менеджменту і міжнародного підприємництва \\ Національного університету «Львівська політехніка», м. Львів \\ К. Р. Кушнір, \\ магістр кафедри менеджменту і міжнародного підприємництва \\ Національного університету «Львівська політехніка», м. Львів
}

\section{ОСОБЛИВОСТІ РОЗВИТКУ ФРАНЧАЙЗИНГИХ ВІДНОСИН В УМОВАХ ПАНДЕМІї}

The article considers the essence of franchising relations due to which small businesses become more competitive and large - strengthen their market position and expand markets for their products. The advantages of franchising are described, the main of which is the possibility of developing your own business with minimal risks during the crisis. Problematic aspects of this form of cooperation for the franchisor and the franchisee are considered, which could be minimized at the stage of signing an agreement. The most popular and developed franchise systems that successfully operate in crisis times are product distribution franchising and business format franchising.

Product distribution franchising means the right to sell the company's product range or provide services under the appropriate brand. As for the franchise of the business format, in this case, the franchisee has not only the right to sell goods or services but the very concept of doing business, i.e., the franchisor transfers all his know-how: from uniforms to training and retraining. The main 
directions of franchising, which began to develop due to the use of information technologies, are considered. Peculiarities of functioning of the domestic and international market of franchising in the conditions of a pandemic among which it is possible to allocate change of organizational and economical format of functioning of the enterprises and growth of popularity of franchises in the field of trade in goods and services. It is proposed to use a franchise of anti-crisis format - a franchise that provides some relaxation on the franchisor part concerning the franchisee in terms of the contract in case of force majeure. Anti-crisis easing and the cases in which they take effect must be stipulated in the contract when concluding it - proposed as practical tools for mobilization and use of resources by the franchisor and the franchisee to form a joint anti-crisis program and the active implementation of digitalization processes. It is necessary to legislate franchising relations at the state level to approve the mechanism of their insurance and financing.

У статті розглянуто сутність франчайзингових відносин завдяки яким малі підприємства стають більш конкурентоспроможні, а великі - зміцнюють свої позиції на ринку $i$ розширюють ринки збуту своєї продукиії. Описано переваги франчайзингу основною з яких $\epsilon$ можливість розвитку власного бізнесу з мінімальними ризиками в період кризи. Розглянуто проблемні аспекти цієї форми співпраці для франчайзера та франчайзі, які можна було б мінімізувати ще на етапі підписання між ними угоди. Досліджено найбільш популярні $i$ розвинуті франчайзингові системи, які успішно функиіонують в умовах кризи, це франчайзинг дистрибуції продукту та франчайзинг бізнес-формату. Франчайзинг дистрибучії продукиії означає право на продаж асортименту товарів компанії чи надання послуг під відповідною торговою маркою. Щодо франчайзингу бізнес-формату, то в иьому випадку франчайзі володіє не лише правом на продаж товарів чи послуг, а самою конщепцією ведення бізнесу, тобто франчайзер передає всі свої ноу-хау: від уніформи до навчання та підвищення кваліфікації персоналу. Розглянуто основні напрямки фрранчайзингу, які почали активно розвиватися, завдяки використанню інформаційних технологій. Проаналізовано особливості функиіонування вітчизняного $i$ міжнародного ринку франчайзингу в умовах пандемії серед яких можна виділити зміну організаційного $i$ економічного формату функиіонування підприємств $i$ зростання популярності на франшизи в сфері торгівлі товарами і послугами. Запропоновано використання франшизи антикризового формату - ие франшиза, яка передбачає певні послаблення з боку франчайзера по відношенню до франчайзі щодо умов контракту у випадку настання форсмажорних обставин. Антикризові послаблення і випадки, за яких вони вступають в силу, мають бути обумовлені в контракті, при його укладанні. Запропоновано в якості ефективних інструментів мобілізації $i$ використання ресурсів франчайзером $i$ франчайзі формування спільної антикризової програми і активне впровадження діджиталізачії прочесів. На державному рівні потрібно законодавчо врегулювати франчайзингові відносини, затвердити механізм їх страхування $i$ фінансування.

Keywords: franchising; franchisor; franchisees; franchise; pandemic; anti-crisis franchise.

Ключові слова: франчайзинг; франчайзер; франчайзі; франшиза; пандемія; антикризова франшиза.

Problem definition and its relationship with important scientific and practical tasks. The functioning of the modern market is impossible without small business. They react more dynamically to any changes in the market. But starting and developing a small business requires significant resources to ensure its economic efficiency. In turn, franchising is a universal mechanism that allows increasing this efficiency and promotes goods in both international and national markets. The essence of franchising is that a large parent company gives the right to a small business for a certain period of time and in a particular place to conduct business using its brand, production technology, know-how in a form determined by the terms of the contract. Thus, franchising provides benefits to small and large companies, i.e., small businesses become more competitive, and large - strengthen their market position and expand markets for their products. In general, the development of franchising is facilitated by globalization processes; for some companies, franchising is the only opportunity to enter foreign markets. However, the worldwide pandemic has caused many problems that franchisees have to deal with. 
Analysis of recent research and publications, which initiated the solution of this problem Many scientific papers and research have been conducted on franchising development by such scientists as G. Androschuk, I. Boychuk, D. Zemlyakov, O. Korolchuk, O. Kuzmin, A. Lutsevich, V. Lyashenko, M. Makasheva, I. Rykova, D. Stanworth, O. Trushenko, A. Tsyrat, and others. Entrepreneur Media Inc studies the franchising trends in the world, the results of which, in particular, the ratings of franchises in various categories, are posted on the company's website.

Objectives of the article The pandemic has forced franchisees worldwide to quickly address the problems it has caused to preserve their business. This article will consider the franchise market's development trends under the influence of the pandemic, the peculiarities of franchising business, and ways out of the crisis.

Presentation of the main material of the study with a full justification of the obtained scientific results. The basis of the franchise system is a franchise package or franchise license. The standard franchise package should include trademark, know-how, franchise guide, services provided by the franchisor to the franchisee, and deductions in favor of the franchisor. A trademark can be pictures, words, numbers, certain pictorial elements, or a melody. Knowhow is professional knowledge, experience in the production of a particular product or service. The franchise guide should include a detailed description of all the procedures that the franchisee may need in further work. The main service that the franchisor provides to the franchisee is support. The scope of these services may vary depending on the type of activity and will include training in the implementation of the franchise, assistance in choosing the premises, equipment, provision of standard software and marketing technologies. The franchisor must describe all the deductions, structure, and amounts that the franchisee will pay to the franchisor. Deductions can be made in the form of a lump sum, royalties, and marketing deductions [8].

The advantage of franchising for the franchisor is that it minimizes investment and provides increased profits. The disadvantage is the transfer of failures of the franchisee to the franchisor, i.e., the defeat of the franchisee in business conduct, in turn, can affect the reputation of the entire brand. The franchisee becomes a separate entity and is fully responsible for the employees and, accordingly, for their results. He must invest a significant amount in the franchise and meet the franchisor's requirements to create and run a business. The franchise's cost directly depends on the size of the franchisor's business and its share in the world market, as well as on the range and clarity of the business concept. When concluding an agreement, the franchisee must adhere to all standards and sell only the franchisor's trademarks, purchase resources from certain suppliers and sell them in specific markets. As for the advantages of this type of business for the franchisee, then, of course, it is joining a successful company whose brand is already known, and therefore, the risk of bankruptcy during the business is much lower than in individual entrepreneurship.

Speaking of the most developed franchising systems, which have retained their position in the pandemic, it is certainly a product distribution franchise and business format franchising. Product distribution franchising means the right to sell the company's product range or provide services under the appropriate brand. This system of franchising relations is the most represented in Ukraine. As for the franchise of the business format, in this case, the franchisee has not only the right to sell goods or services but the very concept of doing business, i.e., the franchisor transfers all his know-how: from uniforms to training and retraining $[1 ; 3 ; 4]$.

Today, the Ukrainian franchise market has slowed down, as has the European or United States market. However, foreign franchises are more stable and continue to operate in Ukraine and around the world. For example, FitCurves is a US-based fitness franchise, Yves Rocher is a French cosmetics company, and of course, the product distribution franchises Pull and Bear, Oysho, Zara Home, Uterqüe, Stradivarius, Lefties, and Bershka, which are part of the group's Spanish retail network of Inditex companies.

Domestic franchises account for $80 \%$ of the national franchise market; the rest are foreign, of which: $8 \%$ - for European, 6\% - for CIS countries, 4\% - for American, 1\% - for Asian, 1\% - other countries. Domestic franchises are in demand in the Ukrainian market, first of all, since their price is more affordable, and establishing relationships is relatively easier. However, franchises of foreign companies operating in the Ukrainian market remain quite popular. The reason for this is the high brand awareness, well-known brand, effective marketing policy, and more. More than 30 Ukrainian franchise projects operate on the international market. The following franchises are most successful in conquering international markets: Khinkalnya, Fresh Line, Lviv Chocolate Workshop, My Coffee, Dream Hostel, Miniboss, AMAKids, Haircut Express, Delfast. Today, franchises remain popular on the market: fitness clubs, wellness centers, private clinics, and laboratories, educational [13].

In the European Union, about $60 \%$ of the economy is provided by franchised companies, and $33 \%$ of the total number of franchises in Europe are of American origin.

Among European countries, the franchise market's leading position is occupied by France (45\% of the total European franchise market) - more than 1,900 franchisors and 71,508 franchisees, with an annual turnover of 55.1 billion euros. The peculiarity of the French franchise market is that it is not attractive for foreign franchise systems.

The franchise market in Poland has about 83,000 franchisees and 1,310 franchise networks. Franchising in Poland is mainly concentrated in retail, catering, and pharmacies.

Today, foreign entrepreneurs have certain advantages in franchising development because they have accumulated rich experience in developing cooperation in this area. Besides, the development of franchising abroad is facilitated by specifically targeted loans, which are encouraged by governments. In Ukraine, lending to franchise projects is difficult due to their high level of risk and the lack of legislation that would regulate the relationship between the franchisor and the franchisee.

From the beginning of 2020, companies have been forced to adapt their activities to the difficult conditions of operation in a coronary virus pandemic. The range of changes in the functioning of companies worldwide is extensive: from the temporary closure of business, limited work, and the complete preservation of efficiency, even with the expansion of the range [9]. The most affected companies were banned due to quarantine restrictions, namely 
entertainment, beauty, restaurant business, tourism, and non-food trade. Besides, companies that have recently started operations and those that have not been able to continue to pay rent have suffered. However, the demand for franchises of those franchise systems that have proven to be anti-crisis in a challenging period for business, in a pandemic, quickly adapted business concepts to environmental conditions, optimized business processes, maintained market share [13]. Leaders of large companies have grown interested in digital transformation and online and virtual franchises, which have changed the structure of operations worldwide.

The tremendous demand in the world, even in a pandemic, are franchises of American companies. According to the Top 100 Franchises 2020 ranking, out of the top twenty, only two franchises are non-American, namely: the English hotel business franchise - InterContinental Hotels and Resorts - 10th place and the Japanese children's education franchise - Kumon - 20th place. Of these 20 companies, 11 operate in the food industry, respectively, operating in a business format. The ranking of the world's ten best franchises that operate successfully in a coronavirus crisis is presented in the table [10].

Table

The 10 best franchises in the world in 2020 from The Franchise 500 [8;10]

\begin{tabular}{|c|c|c|c|c|c|}
\hline Company & Country & Industry & $\begin{array}{l}\text { Initial cost of the } \\
\text { franchise }\end{array}$ & $\begin{array}{l}\text { Number of } \\
\text { franchises }\end{array}$ & $\begin{array}{c}\text { Year of } \\
\text { franchise sales }\end{array}$ \\
\hline Dunkin’ & USA & $\begin{array}{l}\text { Franchise of bakery products } \\
\text { and donuts }\end{array}$ & $\begin{array}{l}\$ 395,500-\$ 1.6 \\
\text { mil. }\end{array}$ & 12957 & 1955 \\
\hline Taco Bell & USA & Fast food franchise & $\begin{array}{l}\$ 525,500-\$ 2.96 \\
\text { mil. }\end{array}$ & 7136 & 1964 \\
\hline McDonald's & USA & Fast food franchise & $\$ 1.3$ млн - \$2.2 mil. & 38108 & 1955 \\
\hline Sonic Drive-In & USA & Fast food franchise & $\$ 1.2$ млн - \$3.5 mil. & 3600 & 1959 \\
\hline The UPS Store & USA & $\begin{array}{l}\text { Shipping and delivery } \\
\text { franchise }\end{array}$ & $\begin{array}{l}\$ 138,400- \\
\$ 470,000\end{array}$ & 5166 & 1980 \\
\hline $\begin{array}{l}\text { Ace Hardware } \\
\text { Corporation }\end{array}$ & USA & $\begin{array}{l}\text { Franchise for retail trade in } \\
\text { non-food products }\end{array}$ & $\begin{array}{l}\text { \$286,000 - \$2.1 } \\
\text { mil. }\end{array}$ & 5312 & 1976 \\
\hline Planet Fitness & USA & Franchise fitness clubs & $\$ 1.1$ млн - \$4.2 mil. & 1859 & 2003 \\
\hline $\begin{array}{l}\text { Jersey Mike's } \\
\text { Subs } \\
\end{array}$ & USA & Sandwich franchise & $\begin{array}{c}\$ 237,400- \\
\$ 766,970 \\
\end{array}$ & 1,592 & 1987 \\
\hline Culver's & USA & Fast food franchise & $\begin{array}{l}\text { \$1.97 млн - \$4.7 } \\
\text { mil. }\end{array}$ & 715 & 1988 \\
\hline $\begin{array}{l}\text { Pizza Hut } \\
\text { LLC }\end{array}$ & USA & Pizza franchise & $\begin{array}{l}\$ 357,000-\$ 2.2 \\
\text { mil. }\end{array}$ & 17,176 & 1959 \\
\hline
\end{tabular}

It is worth noting that the best franchises in the world are the franchises of the United States of America, which belong to the food industry. Of the ten franchises presented, only three do not relate to food, namely: The UPS Store (delivery franchise), Ace Hardware Corporation (non-food retail franchise), and Planet Fitness (fitness club franchise).

However, according to a report by the International Franchising Association (IFA), 32,700 franchises have closed since the pandemic in the United States, 21,834 of these franchises have been closed temporarily 10,875 have been closed permanently. As a result, 1.4 million people became unemployed. Undoubtedly, the figures for Ukraine are not so large-scale and negative, but all countries felt the decline in this business.

The franchise industry is much more extensive than just franchisors and franchisees. In the pandemic context, the demand for consulting companies' services that help franchisors and franchisees run their business success has increased. These consultants can be grouped by their areas of activity: accounting, banking and financing, franchise brokers and referral networks, franchising and development consulting, legal services, marketing, trade services, public relations, real estate services, and technology services.

The leading consulting companies in the field of franchising in the global market are Marketing - an American franchise marketing agency, A\&G - provides full accounting services (USA), Accurate Franchising - a consulting firm for franchise development (USA), All Points Public Relations - a company that operates in the field of advertising and marketing, is engaged in the promotion of franchises (USA), ApplePie Capital - a company engaged in franchising (USA) [8].

The crisis caused by the pandemic has intensified the development of the market for information technology (IT) franchises. It is a relatively new industry that has grown over the past few decades with the growth of the Internet, smartphones, and other technological advances and is relevant in today's complex environment. Today, appropriate technologies are needed to run a successful business. Billions of people need reliable services that can provide them with the help and guidance they need due to technological difficulties, and the computer and IT services franchise fully provide it. Many franchisees that provide computer and IT services have low start-up costs because they do not require a storefront or a large amount of equipment. Many of these franchises offer their services remotely. The most developed franchises for computer and IT services are TeamLogic Inc., Experimax, and CMIT Solutions, Inc. [10].

Based on the research, we can identify the following features of franchising in a pandemic [9;12;13]:

1. Closing the franchisee since they: did not have time to develop a business based on the franchise; did not fulfill the terms of the agreement with the franchisor; the franchisor has ceased its activities; worked in areas affected by the crisis; could not adapt to change; could not switch to the online format of doing business (trade in non-food 
products, entertainment, restaurants, health and beauty industry, tourism and air transport, education, leisure, recreation).

2. Digitalization of business through the active use of Internet technologies and computer programs has become a positive moment for the preservation and development of business. Digitalization has provided: efficient use of working time, improved communication within the enterprise and with the external environment, reducing the complexity of operations, improving customer service, and more.

3. Active development of franchising in the medical field through the sale of franchises for the opening of pharmacies, medical laboratories, diagnostic centers, which provides greater availability of these organizations' services for consumers.

4. Relative stability in the operation of franchises of coffee shops, fast food, pastries, private kindergartens, pawnshops, delivery services, which ensured the preservation of employment in these areas.

5. The emergence of the franchise market franchises anti-crisis format, which are characterized by a decrease in the requirements of the franchisor to the franchisee for the area of the franchisee and its location; adjustment of prices for products or services per consumer income; number of employees and range; placement of points of sale, their internal and external design and equipment; terms of purchase of raw materials and products, product range, marketing and advertising; the market for goods or services; selection of resource providers. Today, the anti-crisis nature of franchises has been ensured by the fact that some franchisors have only reviewed the term, structure, and amount of payments and conducted consultations and training of franchisees' staff.

Anti-crisis franchises are franchises that provide certain relaxations on the franchisor part in relation to the franchisee in terms of the contract in the event of force majeure. Anti-crisis conditions and the moment of their entry into force must be stipulated in the contract at its conclusion. Moreover, the main condition for concluding such a franchise should be the franchise agreement's insurance, which would minimize the risks for participants. However, today, there are no effective tools to support franchising by the state, financial, and insurance institutions, which complicates this type of relationship.

6. Decrease in demand for franchises, both domestic and foreign, due to the high risk of investing in franchises.

7. Increasing demand for pawnshop franchises and microfinance, as well as for various delivery services.

8. Decreased interest in online and online franchises.

9. Increasing the number of franchises, especially in the field of postal services, in villages and small towns.

Summing up the research results, in current crisis conditions, an effective tool for mobilization and use of resources would be the formation of the franchisor and the franchisee of a joint anti-crisis program, the use of anti-crisis franchises, and active use of digitalization processes. It is necessary to legislate franchising relations at the state level to develop a mechanism for its operation, insurance, and financing.

Conclusions. Observing the development of franchising in the world, we can conclude that it is more resistant to change than individual business because it has substantial roots that are growing around the world. Speaking of the most popular franchises globally, they are certain franchises of the United States in the field of nutrition, operating on a business format. There is also a well-developed product distribution system, which can be seen in the example of worldfamous clothing brands. Franchising is a universal tool for developing your own business with minimal risks. Starting an individual business from the beginning, the future entrepreneur risks losing everything because consumers may not be interested in his product. Buying a successful, well-known franchisee only needs to fulfill all the terms of the agreement and make a profit.

In the franchising industry and the franchisee and the franchisor, other companies provide services and products to help franchisors and franchisees succeed in doing business. Assistance can be provided in various areas, from accounting and legal services to marketing and public relations.

It is worth noting that the global pandemic has become a test of this century, which has damaged both the global economy as a whole and individual businesses. Observing the development of international franchising in a worldwide pandemic, it is worth noting the rapid growth in online franchises' popularity, especially in the medical field. In turn, for the period of quarantine restrictions, there was a decrease in the cost of franchises of companies that were forced to suspend their activities or change the format of operation. Accordingly, some franchisors have reduced flatrate rates, royalty interest rates and updated their franchises' forms. Undoubtedly, COVID-19 has caused significant damage to people worldwide. However, it is worth noting that it has opened up new opportunities for development and improvement for some businesses, especially in the service sector.

\section{Список використаних джерел.}

1. Данніков О. В Проблеми побудови та функціонування франчайзингових систем в Україні // Маркетинг в Україні. - 2008. - №5(51). - С. 62-69.

2. Лебедєва І. Л. Франчайзинг: можливості зростання в умовах кризи / І. Л. Лебєдєва, В. Ю. Мавріду // Управління розвитком : зб. наук. статей. - Х. : ХНЕУ, 2009. - №15. - С. 108-109.

3. Корольчук О. П. Франчайзинг (теорія, методологія, практика) : монографія / О. П. Корольчук. - К. : Київ. нац. торг.-екон. ун-т, 2006. - 207 с

4. Саркисян М. А. Виды и формы франчайзинга, их развитие в современных условиях // Актуальные исследования. 2020. №13 (16). С. 61-66.

5. Цират А. В. Франчайзинг и франчайзинговий договор / А. В. Цират. - К. : Истина, 2002. - 240 с.

6. Холодный Г. А. Состояние франчайзинга на зарубежном и отечественном рынке / Г. А. Холодный, Т. П. Прохорова, Т. И. Притыченко, В. Ю. Мавриду // Бизнес Информ. - 2006. - № 8. - С. 50-59. 
7. Офіційний сайт федерації франчайзингу. Глосарій франчайзингу. [Електронний ресурс]. - Режим доступу: http://fdf.org.ua/about-franchise/glossary

8. Entrepreneur Media, Inc.Top Global Franchises Ranking 2020. [Електронний ресурс]. — Режим доступу: https://www.entrepreneur.com/franchises/topglobal

9. Онлайн-платформа «Дія. Бізнес». Тренди франчайзингу в період кризи 2020-2021. [Електронний pecypc]. - Режим доступу: https://business.diia.gov.ua/handbook/francajzing/trendi-francajzingu-v-period-krizi2020-2021

10. Franchisedirect. Top 100 Franchises 2020. [Електронний ресурс]. - Режим доступу: https://www.franchisedirect.com/top100globalfranchises/rankings

11. Franchising.ua. Франчайзинговий пакет. [Електронний ресурс]. - Режим доступу: https://ru.franchising.ua/franchayzing/14/franchayzingovyy-paket/

12. Inventure. Франчайзинг и лучшие франшизы в Украине в 2021году. [Електронний ресурс]. Режим доступу: https://inventure.com.ua/analytics/articles/luchshie-franshizy-v-ukraine-v-2019-po-versii-inventure

13. Офіційний сайт франчайзингової групи в Україні. Аналіз ринку франчайзингу України 20092020pp [Електронний pecypc]. Режим доступу:https://franchisegroup.com.ua/media/files/report/FG_\%D0\%B0\%D0\%BD\%D0\%B0\%D0\%BB\%D1\%96\%D0 $\%$ B7\%20\%D1\%80\%D0\%B8\%D0\%BD\%D0\%BA\%D1\%83\%202020.pdf

14. Шкиль В. В Украине работает 700 франшиз. Какие самые перспективные и почему бизнес по франшизе - это непросто. [Електронний ресурс]. — Режим доступу: https://mc.today/v-ukraine-rabotaet-700franshiz-kakie-samye-perspektivnye-i-pochemu-biznes-po-franshize-eto-neprosto/

\section{References.}

1. Dannikov, O. V. (2008), "Problems of construction and functioning of franchising systems in Ukraine", Marketynh v Ukraini, vol. 5 (51), pp. 62-69. pp. 108-109

2. Lebedeva, I. L. (2009), "Franchising: opportunities for growth in a crisis", Upravlinnia rozvytkom, vol. 15,

3. Korolchuk, O. P. (2006), Franchajzyng (teorija, metodologija, praktyka [Franchising (theory, methodology, practice)], Kyiv nac. torg.- ekon. un-t, Kyiv, Ukraine.

4. Sarkisyan, M. A. ( 2020), "Types and forms of franchising, their development in modern conditions", Aktual ny'e issledovaniya, vol. 13 (16), pp.61-66.

5. Tsirat, A. V. (2002), Franchajzing i franchajzingovij dogovor [Franchising and franchising agreement], Istina, Kyiv, Ukraine.

6. Kholodny, G. A. Prokhorova, T. P. Pritychenko, T. I. and Mavridou, V. Yu. (2006), "The state of franchising in the foreign and domestic market", Biznes Inform, vol 8, pp. 50-59.

7. The official site of Federation of Franchising (2020), "Glossary of franchising", available at: http://fdf.org.ua/about-franchise/glossary (Accessed 14 March 2021)

8. Entrepreneur Media, Inc. (2020), "Top Global Franchises Ranking 2020", available at: https://www.entrepreneur.com/franchises/topglobal (Accessed 14 March 2021)

9. Online platform "Action. Business" (2021), "Franchising trends during the crisis 2020-2021", available at: https://business.diia.gov.ua/handbook/francajzing/trendi-francajzingu-v-period-krizi-2020-2021(Accessed 7 March 2021)

10. Franchise Direct (2020), “Top $100 \quad$ Franchises 2020", available at: https://www.franchisedirect.com/top100globalfranchises/rankings (Accessed 24 March 2021)

11. Franchising.ua "Franchising package", available https://ru.franchising.ua/franchayzing/14/franchayzingovyy-paket (Accessed 24 March 2021)

12. Inventure (2021), "Rating of the TOP 50 most popular franchises of Ukraine in 2021 in the most popular areas of activity: catering, services and trade", available at: https: //inventure.com.ua/analytics/articles/luchshiefranshizy-v-ukraine-v-2019-po-versii-inventure (Accessed 1 March 2021)

13. Official site of the franchising group of Ukraine (2021), "Analysis of the franchising market of Ukraine 2009-2020", available

https://franchisegroup.com.ua/media/files/report/FG_\%D0\%B0\%D0\%BD\%D0\%B0\%D0\%BB\%D1\%96\%D0\%B7\%20 $\% \mathrm{D} 1 \% 80 \% \mathrm{D} 0 \% \mathrm{~B} 8 \% \mathrm{D} 0 \% \mathrm{BD} \% \mathrm{D} 0 \% \mathrm{BA} \% \mathrm{D} 1 \% 83 \% 202020 . \mathrm{pdf}$ (Accessed 9 March 2021)

14. Shkil, V. (2020), "There are 700 franchises in Ukraine. What are the most promising and why a franchise business is not easy?", available at: https://mc.today/v-ukraine-rabotaet-700-franshiz-kakie-samye-perspektivnye-ipochemu-biznes-po-franshize-eto-neprosto (Accessed 16 March 2021). 